\title{
Story Mapping Strategy to Teach Reading Comprehension Achievement
}

\author{
Sundari', Zulaikah ${ }^{2}$, and Dwi Andriani ${ }^{3}$ \\ Pendidikan Bahasa Inggris STKIP Nurul Huda Sukaraja \\ 's sundaritwisby@mail.com \\ zulaikah@stkipnurulhuda.ac.id \\ 32dwiandriani@stkipnurulhuda.ac.id
}

\begin{abstract}
The objective of this study was to find out whether or not there are any significant differences between students who are taught by using story mapping strategy and students who are not taught by using story mapping strategy in teaching reading comprehension at the tenth-grade students of MA Subulussalam OKU Timur. This study used an experimental method, by quasi-design. Meanwhile, the population was the tenth-grade students of MA Subulussalam Oku Timur with total students were 151. The sample was 71 students, consist of two groups, namely experimental class consist of 34 students, and control class consists of 37 students which chosen by using purposive sampling. In this study, the writer used SPSS 16 to analyze. The result of this research shows that the story mapping strategy was effective in teaching reading comprehension at the tenth-grade students of MA Subulussalam OKU Timur.
\end{abstract}

\section{Key Words: Story mapping strategy, Reading Comprehension.}

\section{INTRODUCTION}

A language is a form of social behavior; it is communication, and communication occurs between and among people (Oxford, 1990: 144). Language is at the heart of human life. Without it, many of our most important activities are inconceivable (Cook, 2003: 2). It means language holds very important in a role delivering information from one to the other. Without language, or every people can't interact each other in daily life. There are many languages in this world. One of them is English.

English is an important language, especially when people go abroad. The importance of the role of English in the International at the moment cannot be denied, English as a global language of communication will increasingly be used in various aspects of international activities. According to Cook (2003: 13) four hundred million or so first-language speakers, and over a billion people who live in a country where it is an official language, English now taught as the main foreign language in virtually every country and used for business, education, and access to information by a substantial proportion of the world's population. See the role of English now in various aspects, the Indonesian government included English into the school curriculum taught to students.

In learning English, four language skills should be learned by students, they are listening, speaking, reading, and writing (Maxom, 2009: 138). Reading holds an important rule in the learning process. In the reading activity, students are asked to comprehend their learning material better. Students' reading comprehension is quite important for both the teacher and the students to know how well students have already understood the material (Farichah, 2017: 417). But in fact, learning reading is not easy for Indonesia students. According to the Program for International Students Assessment (2018), the reading ability of Indonesian students is ranked 62nd out of 70 countries. It shows that Indonesian students have low comprehension in reading.

Besides, the writer did observation to find the problem occurring by interviewing an English teacher at MA Subulussalam OKU Timur. It was found that the score of students in reading comprehension was still low. It caused some reasons, such as The students got difficulties in understanding a reading text, it was because they only focused on translate the meaning word for 
word rather than understanding the whole content of the text. Furthermore, the students were also lazy and bored to read a text especially a long text. Overall, it made the student could not get important information about the text. Moreover, the writer was interested in trying to find an effective way to help the student more interested and active in the teaching and learning process.

Here, the writer applied a reading strategy. Pourhoseingilakjani (2016: 237) stated that reading strategies have a great impact on the students' reading comprehension ability. Students are not just passive receivers of information but they are active makers of meaning. There are many strategies can be used in teaching reading comprehension. One of them is the story mapping strategy. Based on Sholichah (2017) story mapping strategy is an effective way of improving students' reading comprehension achievement. Story mapping strategy can help students to organize the information by finding and writing the keywords of the text. Each keyword in the story map represents certain information in the reading text. It makes students can easily to recall the message of the text. Therefore, story mapping strategy can also eliminate students' boredom in the class, most students enjoy when reading the text.

\section{Concept of Reading}

Reading is an important skill for students in the learning process. It can be a key to achieve the goal of teaching-learning, especially in English learning. By reading, students can find out the information and also will know and understand what they read. Pang, Muaka, Bernhardt, \& Kamil (2003: 6) stated that learning to read is an important educational goal. For both children and adults, the ability to read opens up new worlds and opportunities. It enables us to gain new knowledge, enjoys literature, and do everyday things that are part and parcel of modern life, such as: reading the newspapers, job listings, instruction manuals, maps, and so on.

Moreover, Pang et al. (2003: 6) said that reading is about understanding written texts. It is a complex activity that involves both perceptions and thought. Reading consists of two related processes, they are word recognition and comprehension. Word recognition refers to the process of perceiving how written symbols correspond to one's spoken language. Comprehension is the process of making sense of words, sentences, and connected text. The reader typically makes use of background knowledge, vocabulary, grammatical, knowledge, experience with the text and another strategy to help them understand written text.

\section{Concept of Reading Comprehension}

Reading comprehension is defined as the process of simultaneously extracting and constructing meaning through interaction and involves written language (Snow, 2002: 11). Therefore, comprehension is not a passive process, but an active one. Comprehension is the process of deriving meaning from connected text. It involves word knowledge (vocabulary) as well as thinking and reasoning. The reader actively engages with the text to construct meaning. This active engagement includes making use of prior knowledge. It involves drawing inferences from the words and expressions that a writer uses to communicate information, ideas, and viewpoints (Pang et al., 2003: 14). By the statements above, it can be concluded that reading comprehension is an active process. It is a deep process to understand and get info- 6 "'on about the text.

\section{Concept of Text Types}

In English there are four skills: listening, speaking, reading, and writing. All of the skills are developed from various types of text. Setiadi, Hutauruk, Santoso, \& Kustanti (2012), cited in Sofyan (2016:11) said that in English can be classified into several types of text as follows:

1. Narrative

A narrative is a piece of writing that tells a story. The story can be imaginary or based on a real incident. A narrative always deals with some problems which lead to the climax and then turn into a solution to the problem. Communication purposes of this text are to tell a story about 
something or someone and to amuse or entertain the readers or listeners.

2. Spoof

A spoof is a humorous story that tells events in a chronological sequence with a twist (unexpected ending). The communication purpose is to entertain readers with an amusing story.

3. Recount

A recount is a piece of writing that tells events in chronological sequence. A recount text is similar to the narrative text. The story may be an event or a situation that took place on a particular day. The communication purpose of this text is to reconstruct past experiences by retelling events in order in which they have occurred.

4. Procedure

A procedure is a piece of writing which consists of instructions to follow. The Communicative purpose of this text is to tell the step in doing or making something in sequential order.

5. News Item

A news item is a piece of writing about an important event or situation that happens on a particular day. The communicative purpose is to inform the readers or listeners of the details of events, accidents, or incidents that have happened.

6. Report

A report provides factual information about a specific subject like social phenomena, nature, and man-made things. Communication's purpose is to give factual information about a specific subject.

7. Description

A description is a piece of writing that lists the characteristics of a person, place, or thing. It describes living or nonliving things such as animals, buildings, and lawns. The communication purpose is to describe a particular person, place, or thing.

8. Explanatory

An explanatory is a piece of writing that gives straightforward information. It explains the process related to the formation of natural, social, scientific, and cultural phenomena. Communication purpose is to enable the readers to understand the process involved in the formation or working of natural, social, scientific, and cultural phenomena.

9. Analytical Exposition

An analytical Exposition is a piece of writing that tries to convince the readers to agree with the writer's viewpoint by analyzing a certain issue within the text. The communicative purpose is to put forward a viewpoint about something.

10. Discussion

A discussion is a piece of writing that explores the pros and cons or the advantages and disadvantages of an issue to allow the readers to reach a logical conclusion. A balanced view of the writer is reflected throughout the writing.

According to the English syllabus, types of texts that are taught in the tenth grade of Islamic Senior High School are descriptive, recount, and narrative text. In this study, the writer focused on descriptive text only.

\section{Concept of Descriptive Text}

Descriptive text is one of the English lessons that should be mastered not only in junior high school but also in senior high school. Hidayati (2016: 80) said descriptive text is a type of text used to describe animals, humans or objects will be described. The object described in the descriptive text is specific, for example, My cat, My beautiful friend, or Anna's favorite doll. Usually, what is described includes physical characteristics and properties for animals and humans. While in other objects special characteristics or physical characteristics can be described. Moreover, in descriptive text consist of generic features, they are: Using specific participants, Using simple present tense, using adverbs that indicated habits, using Pronouns. Therefore, based on Hidayati (2016: 80-81) the 
generic structure as follows:1) Identification: In this part, you should introduce the object that you will describe in a concise and clear language.2) Description: In this part become the core in descriptive text. It contains a complete description of the object that must be described include physical characteristics, character, habits, etc.

\section{Concept of Story Mapping Strategy}

Story Mapping is a kind of strategy used in teaching reading comprehension by asking students to identify story text by using a specific structure. In this strategy the students are given a story map, the story map includes specific parts of the story. Then, they determine story elements or categorizing the main evens in the sequential order of the text and put it in their story map to represent the information. Anggraeyni (2015: 3) stated that the story mapping strategy is used after a story has been read. It includes identifying the main elements, categorizing the main events in sequence order. A graphic representation is often used to illustrate the story structure and sequence of events. Moreover, Jackson and Pillow (1992) stated story mapping can be applied to all types of writing (descriptive, narrative, etc).

The story mapping strategy is interesting and useful to teach reading comprehension. According to Sayeski and Paulsen (2003: 16) stated in story mapping students can draw pictures to represent the sequence or write down the keywords. The teacher can create their story maps with headings to match their instructional goals. It meant that teacher can create a story map appropriately for the type of assigned reading.

Furthermore, the story mapping strategy can improve the reading comprehension achievement of the student. Sholichah (2017: 45) stated that the story mapping strategy is effective in improving the students' reading comprehension achievement may be caused by some reasons. Firstly, by doing the story mapping strategy while reading the texts, the students can find the main idea, inference and can improve the students' vocabulary. The story mapping after reading the texts, the students can easily recall the message of the text when it comes to the comprehension exercises, the students can look at the story mapping containing the keywords of the texts and its description. Each keyword in the story mapping represents certain information in the reading texts, then, it is supported by the description of the keywords. Secondly, the students taught by the story mapping strategy have higher motivation in reading the texts. Thirdly, the story mapping strategy can avoid the students' boredom while reading the texts.

\section{* Advantages and Disadvantages of Story Mapping Strategy}

Sholichah (2017: 43) stated some advantages of story mapping strategy as follows:

1. The implementation of the story mapping strategy can help students to organize the information they get from the reading material in an affective way. By training students to find keywords of each paragraph and write down the information of the keywords provided the opportunities for students to recall the detail information from the reading materials.

2. The implementation of the story mapping can prevent the students' boredom.

3. The story mapping strategy is an effective way of improving students' reading comprehension achievement.

Furthermore, Anggraeyni (2015: 5) stated the disadvantages of using a story mapping strategy as follows:

1. The teacher will be busy to manage the class.

2. It will take a quite long time for the students in understanding the steps of the story map. So, the teacher should help students to manage the time.

\section{* Teaching Procedures by Using Story Mapping Strategy}

For teaching reading comprehension by using story mapping strategy as follows:

1. The teacher asks students to do silent reading a text. In this time, students read a text without 
voice and move the lips for seven minutes.

2. After seven minutes, the teacher asks students to stop reading and distributes each student the worksheet (story map). The worksheet contains the main idea and detail.

3. The teacher asks students to count to create groups.

The students in groups are asked to determine the main idea and detail of the text independently.

Then, they discuss it together. After that, they put it in their worksheet to represent the information.

\section{METHODOLOGY}

The writer used quantitative research. In quantitative research. The quantitative research has two methods commonly used, namely the survey method and experimental method (Sugiyono, 2013). Meanwhile, Sugiyono (2016: 73) classified the experiment into four types, they are Pre-experimental design, true experimental design, factorial experimental design, and quasi-experimental design. Whereas the design used in this study was quasi-experimental. According to Creswell (2012:309) in quasi-experimental design, we can apply the pretest and posttest. Include assignment, but not a random assignment of participants to groups. Two groups consisting of two classes were used as the sample in this design, they were the experimental class and control class. Two classes were given the same materials on the same topics. The experimental class was taught by using story mapping. Before the treatment, a pretest was given both of the classes. After treatment, the posttest of the instrument was given to them. It can compare the students' abilities in the experimental class and control class.

The research variables are an important guideline in conducting the study, there were two variables, namely the dependent variable and independent variable. The dependent variable was students' reading comprehension achievement and the independent variable was story mapping. Besides, the population of this study was the tenth-grade students of MA Subulussalam OKU Timur. with the total number of the population are 151 students consisting of 4 classes, the writer choose purposive sampling to determine sample from the four classes of the tenth-grade students of MA Subulussalam OKU Timur and the total number of the sample of the study was 71 .

Moreover, in collecting the data the writer used a reading comprehension test as the instrument to obtain the students' ability in reading descriptive text. And for analyzing the data by using an Independent t-test.

\section{RESULT AND DISCUSSION}

The writers gave a pretest for the experimental and control group before conduct the experiment and then calculated the students' scores. There were meetings for treatment to the students in teaching reading comprehension by using story mapping, then the writer gave posttest in the experimental and control class.

In this section, the writer presented the findings of the research that was already done findings highlight the result normality, homogeneity, and hypotheses that were taken during the study. It is shown in table 1.

TABLE 1

The Result of Normality, Homogeneity and Independent t-test

\begin{tabular}{|l|l|l|l|l|}
\hline \multirow{2}{*}{} & \multicolumn{3}{|l|}{ Statistical Analysis } & \multicolumn{3}{|l|}{} \\
\cline { 2 - 5 } & Normality & Homogeneity & \multicolumn{2}{|l|}{ Independent t-test } \\
\cline { 2 - 4 } & Kolmogorov-Smirnov & Levene's & Ha & Ho \\
\hline $\begin{array}{l}\text { Experimental } \\
\text { class }\end{array}$ & .171 & \multirow{2}{*}{280} & 3.693 & Rejected \\
\hline Control class & .318 & & Accepted & \\
\hline
\end{tabular}


Sundari ${ }^{1}$, Zulaikah $^{2}$, dan Dwi Andriani ${ }^{3}$

\section{CONCLUSION}

Based on the study that was carried out at MA Subulussalam OKU Timur, the writer concluded as follows: In the previous, the writer had analyzed the data statistically. Based on statistical analysis, there were any significant differences between students who are taught by using story mapping strategy and students who are not taught by using story mapping strategy to teach students' reading comprehension achievement of the tenth-grade students of MA Subulussalam OKU Timur. The significant differences could be seen from t-obtained of the equal assumed in the independent sample t-test where t-obtained was higher than t-table $(3.693>2.000)$ and it meant that Ho was rejected and Ha was accepted.

\section{REFERENCIES}

Anggraeyni, F., Salam, U., \& Suhartono, L. (2015). Improving Students' Reading Comprehension in Finding Elements Story Through Story Mapping Strategy. Jurnal Pendidikan dan Pembelajaran, 4 (3), 1-8.

Cook, G. (2003). Applied Linguistics. New York: Oxford University Press.

Creswell, J. W. (2012). Educational Research: Planning, Conducting and Evaluating Quantitative and Qualitative Research (4th ed.). Boston: Person Education, Inc.

Hidayati, D. N. (2016). Supersmart Book Bahasa Inggris. Yogyakarta: PT Bentang Pustaka.

Jackson, N. R., \& Pillow, P. L. (1992). The Reading-Writing Workshop: Getting Started. New York: Scholastic Inc.

Maxom, M. (2009). Teaching English as a Foreign Language for Dummies. England: John Wiley \& Sons, Ltd.

Oxford, R. L. (1990). Language Learning Strategies: What Every Teacher Should Know. Boston: Heinle and Heinle.

Pang, E. S., Muaka, A., Bernhardt, E. B., \& Kamil, M. L. (2003). Teaching Reading. Switzerland: The International Academy of Education.

Pourhoseingilakjani, A. (2016). How can Students Improve Their Reading Comprehension Skill? Journal of Studies in Education, 6 (2), 229-240.

Sayeski, K., \& Paulsen, K (2003). Early Reading. Retrieved from http://iris, Peabody. Vanderbit.edu/wp/upload/pdf_case_studies/icsearrd.pdf.

Sholichah, N. I. (2017). The Effect of Story Mapping on Reading Comprehension. Jurnal Penelitian IImiah Intaj, 30-48.

Sholichah, N. I. (2017). The Effect of Story Mapping on Reading Comprehension. Jurnal Penelitian IImiah Intaj , 30-48.

Snow, C. (2002). Reading for Understanding: Toward an R\&D Program in Reading Comprehension. Santa Monica: RAND.

Sofyan, M. (2017). The Influence of Readers' Perior Knowledge in Comprehending English Text. Thesis. Faculty of Tarbiyah and Teacher Training Islamic State University of Ar-Raniry, Banda Aceh.

Sugiyono. (2013). Metode Penelitian Pendidikan Pendekatan Kuantitatif, Kualitatif, dan R\&D. Bandung: Alfabeta.

Sugiyono. (2015). Metode Penelitian Kombinasi (Mix Methods). Bandung: Alfabeta. 